ポリエチレンテレフタレート絨維のヤング率と配向度との

関係につにて

䋘維工業試験所 近田淳恠・藤野澄

我妻 直夫

\title{
THE RELATIONSHIP BETWEEN YOUNG'S MODULUS AND DEGREE OF ORIENTAION FOR POLYETHYLENE TEREPHTHALATE FIBRES.
}

By Atsuo Konda, Sumi Fujino and Tadao Agatsuma.

(The Textile Research Institute of the Japanese Government, Sawatari, Kanagawa-Ku, Yokohama City, Japan)

In the previous report, relationship between Young's modulus and birefringence for drawn and heat-treated PET fibres was discussed.

In this report, the mechanism of small deformation of PET fibres below glass transition temperature is discussed and a new theoretical approach between Young's modulus and molecular orientation is proposed under the following assumptions: a) A segment transforms in accordance with "affin deformation" theory: b) Intersegmental force during the affin transformation of the segment is proportional to the rotational angle of the segment.

Then, Young's moduli of PET fibres heat-treated at constant length after drawing and ones drawn after crystallization are measured and compared with the theory. The results obtained are as follows :

1. The rotational angle $\omega$ of a segment due to the deformation of a sample and Young's modulus $E$ may be expressed by following equations :

$$
\begin{aligned}
& \omega=(1+\nu) e_{z} \cos \theta \sin \theta \\
& E=E_{0}\left\{(1+\nu)\left\langle\cos ^{4} \theta\right\rangle-\nu\left\langle\cos ^{2} \theta\right\rangle\right\}+G_{0}(1+\nu)\left\langle\cos ^{2} \theta \sin ^{2} \theta\right\rangle
\end{aligned}
$$

where $\nu$ is Poisson ratio of the sample; $\theta$ is the angle between the fiber axis and the segmental axis ; $e_{z}$ is tensile strain of the bulk sample; $E_{0}$ and $G_{0}$ are constants.

2. The relationship between Young's modulus and amorphous orientation factor may be represented in terms of the above equations. The values of $E_{0}$ and $G_{0}$ are $1700 \sim 1900 \mathrm{~kg} / \mathrm{mm}^{2}, 80 \mathrm{~kg} / \mathrm{mm}^{2}$, respectively, for the samples drawn without heat-treatment, but these are a little smaller for the samples drawn after crystallization.

Young's modulus of drawn PET fibres depends mainly upon amorphous orientation and the effect of crystallinity is rather small.

3. The above results suggest that the force constant of the amorphous segment below glass transition temperature dose not much differ from that of the crystalline chain, but a part of intermolecular strain makes a series to intra-molecular strain and lowers much the Young's modulus of bulk sample; and that there may be more parts of fold structure in samples drawn after crystallization than in ones drawn without heat-treatment.

(Received August 24, 1966)

\section{1.は じめに}

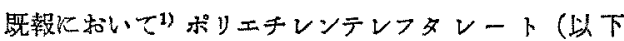
PET の略記) 繊維のヤング率は非晶分子鎖の配向度に
依存し，ヤング率と複屈折度との間に理論式が成立する ことを確かめた。しかし，理諭式の誘導にあたつて，分 子間力による寄与など十分な考察を回避した点もあるの で，再びとりまげて考察を進めた。また，既報では示さ 
なかつた配向度の高い試料についての結果就よび結晶化 した後延伸した試料の結果についてる理論式との対応を 新しい見地から検剖した。さらにX線による結晶配向度 の求め方について，2，3の方法をとりあげて比較检討 した結果を付録に示した。

\section{2. 理論式の再検討}

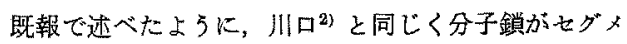
ントあるい弾性的梅効鎖（以後これを要素と呼ふ）に より構成されているものとする。いまこの要素が試料 の变形伴なつて affin 変形すると仮定すると, 試料化 eqのひず双を与えたときの要素のひずみ $e_{a}$ は既報に より次式で与えられる(ガラス状態に括いて)。

$$
e_{a}=e_{Z}\left\{1-(\nu+1) \sin ^{2} \theta\right\}
$$

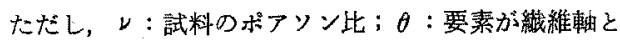
なす角。

したがつて要素に生じている張力の㵶維軸力问への分 力の総和 $F_{a}$ は

$$
\begin{aligned}
& F_{a}=\int_{0}^{\pi / 2} E_{a} e_{a} \cos \theta d n \\
= & m a S E_{a} e_{z}\left[(1+\nu)\left\langle\cos ^{4} \theta\right\rangle-\nu\left\langle\cos ^{2} \theta\right\rangle\right]
\end{aligned}
$$

ただし， $E_{a}:$ 要素の force const.; $d n: \theta \varepsilon \theta+d \theta$ の間の㑯をもつ要索の数(断面を貫通するもの)； $m$ :

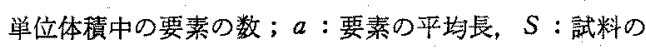
断面積

なお, $d n$ は次式で与えられる（一軸配向の々き） $d n=2 \operatorname{maS}|\cos \theta| P(\theta) \sin \theta d \theta$

ただし， $P(\theta)$ は要素の単位球表面での分布密度関数で

$$
\int_{0}^{\pi / 2} 2 P(\theta) \sin \theta d \theta=1
$$

となるようにとつたものである（既報の $P(\theta)$ は $2 P(\theta)$ $\sin \theta$ である。

既報ではここで分子間エホルギー変化に対応する力を 考文，このための縺維軸方向の力を $F_{G}$ とし，試料に $e_{Z}$ のひずみを与克るたかの外力 $F$ は

$$
F=F_{a}+F_{G}
$$

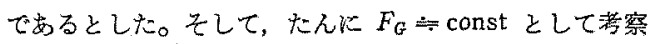
を進めたが，実際に酒向度の高い陚料の $F_{G}$ は零长近 くなるるの之若劣る伍らが妥当である。また，この他分 子鎖の曲げを考虑する必要がある上万思われるが，こ こで考えている要䒺は曲げを無視できる程度以短かいる のでかり，分子鎖の曲げ住要素接合点で起こるすのと考 党てよいであろう。いま， $F_{G}$ は試料の变形化なら琶 菜の回転により発生する要素間相互变位によつて大部分 引き起こされると仮定すれば，高配问試料では零に近つ き，杰た要素接合点での曲げに対する仙力む $F_{G}$ に含ま

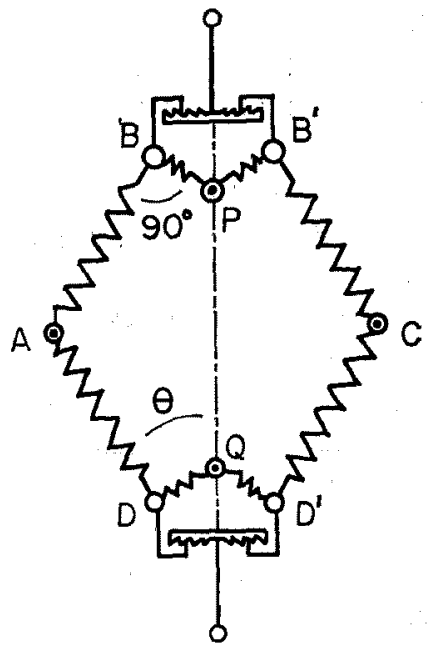

Fig. 1. A mechanical model defining the intersegmental force; the spring $A B$ corresponds to a segment and the spring $B P$ to inter-segmental interaction,

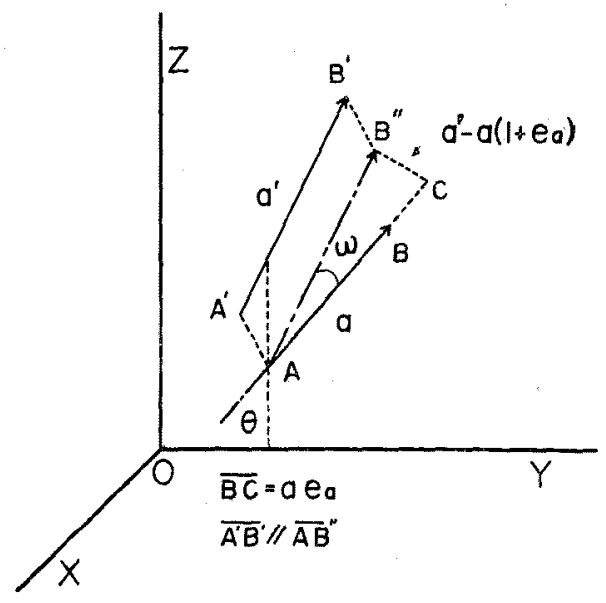

Fig. 2. A schematic diagram for the vector change of a segment with deformation.

せることが可能となり，好都合でかる。闍題はこれらの 各寄与を，直列的加亚列的か，学るい，その他何九の 型により作用させるかといらことである。ここでは単純 $K F_{a}$ と $F_{G}$ とは证列的作用乙，(6)式加成立するす のとする。

力学的なチデルとしては Fig. 1 のようなものを考 え, 試料の微少要形沉伴なつて $\overline{\mathrm{AB}} ， \overline{\mathrm{B}^{\top} \mathrm{C} な と ゙ か ゙ ~ a f f i n ~}$ 変形し( $\overline{\mathrm{AB}} な と ゙ は$ 要素に対応), $\overline{\mathrm{AB}}$ の回転により, $\widehat{\mathrm{PB}}$ 飞登生する力口 $\overline{\mathrm{BD}}$ 方向の成分学 $F_{G}$ と考光る。 
繊維軸を $Z$ 軸とする直交座榑系 $(X, Y, Z)$ を考学， 各軸方向の単位べタトルを $i, j, k$ とする。 $z$ 軸之 $\theta$ 傾

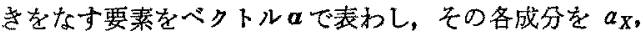
$a_{Y}, a_{Z}$ とすれば

$$
a=a_{X} i+a_{Y} j+a_{Z} k
$$

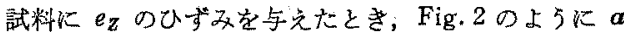
なる要菜が $a^{\prime}$ 炕変化し

で表わされたとする。

$$
\boldsymbol{a}^{\prime}=a^{\prime}{ }_{X}^{i+a_{Y}^{\prime}} j+a^{\prime}{ }_{2}^{k}
$$

試料のポナソン比をレとし，affine 変形を仮定すれば

$$
\left.\begin{array}{l}
a_{X}^{\prime}=\left(1-\nu e_{Z}\right) a_{X}, \quad a_{Y}^{\prime}=\left(1-\nu e_{Z}\right) a_{Y} \\
a_{Z}^{\prime}=\left(1+e_{Z}\right) a_{Z}
\end{array}\right\}
$$

- 方

$$
\left|a^{\prime}\right|=\left|a\left(1+e_{a}\right)\right|
$$

であるから

$$
\left|\boldsymbol{a}^{\prime}\right| \omega=\left|\boldsymbol{a}^{\prime}-\boldsymbol{a}\left(1+e_{\alpha}\right)\right|
$$

ただし， $\omega:$ 要素の回転角

良つて。

$$
\sin ^{2} \theta=\left(a^{2} x+a^{2} y\right) / a^{2}, \cos ^{2} \theta=a^{2} z / a^{2}
$$

を利用すれば

$$
\omega=(1+\nu) e_{2} \cos \theta \sin \theta /\left(1+e_{a}\right)
$$

を得る。

$e_{a} \ll 1$ と考えられるのて

$$
\omega \doteqdot(1+\nu) e_{Z} \cos \theta \sin \theta
$$

となる。

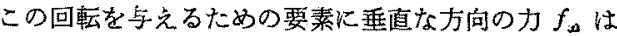
$\omega$ K比例するすのと仮定すれば， $G_{a}$ を比例定数として

$$
f_{\omega}=G_{a} \omega
$$

と店り，繊維軸力向への分力の総和 $F_{G}$ は

$$
\begin{aligned}
F_{G} & =\int_{0}^{\pi / 2} G_{a} \omega \sin \theta \cdot d n \\
& =m a S G_{a}(1+\nu) e_{Z}\left\langle\cos ^{2} \theta \sin ^{2} \theta\right\rangle
\end{aligned}
$$

(3)，(6)，(15)式扣よび

$$
E=F / S e_{Z}
$$

により，試料のヤング率Eは

$$
\begin{aligned}
E & =E_{0}\left\{(1+\nu)\left\langle\cos ^{4} \theta\right\rangle-\nu\left\langle\cos ^{2} \theta\right\rangle\right\} \\
& +G_{0}(1+\nu)\left\langle\cos ^{2} \theta \sin ^{2} \theta\right\rangle
\end{aligned}
$$

ただし， $E_{0}=m a E_{a}, G_{0}=m a G_{a}$

で表わされることになる。

い李，ガラス状態のレとして $0.33^{16)}$ ，完全配向試料 の複屈折度 $\Delta n_{0}=212 \times 10^{-3}\left(\mathrm{Palmer}^{12)}\right.$ による) とし, さらに垁験結果とよく一致するよ5に $E_{0} ， G_{0}$ を定めて (17)式を計算五名と，Fig. 3 の実線が得られる。（ $E_{0}=$ $1700 \mathrm{~kg} / \mathrm{mm}^{2} ， G_{0}=80 \mathrm{~kg} / \mathrm{mm}^{2}$ としたが, $G_{0}$ は shear modulus 飞近い値をとることが予想されるので J. H. Wakelin ${ }^{14)}$ の結果を参考にした。)

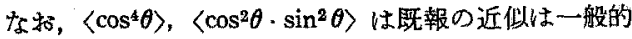
でないので付録Aの上5にして求めた。

結果的には $\left\langle\cos ^{2} \theta \cdot \sin ^{2} \theta\right\rangle$ は $0 \sim 0.14$ 程度で, (17) 式の第 2 項 ( $G_{0}$ の笴与) は非常に小さい。

\section{3. 实験}

\section{1 実験方法}

○未延伸試料：比重 $1,347 \sim 1,349$, 複屈折度 $1.5 \times$ $10^{-3}$, 緎度 $88 \mathrm{~d}, X$ 線的に坆然定形の PET モノフィ メント，括よび，上記試料を沸誉水中 10 分，シリュン 油中, $160^{\circ} \mathrm{C} て ゙ 30$ 分定長熱処理したるの。

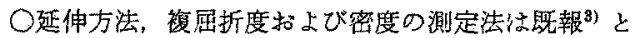
同概で岕る。

○ヤング率の測定：インストロンまたはテンシロン （真洋湘器 K.K. 整）污張試験機に上り，荷重一伸張曲線 を求め，その初期傎斜から計算した。試狺は $5 \mathrm{~cm}$. 引 張速度は $1 \mathrm{~cm} / \mathrm{min}$ である $\left(20^{\circ} \mathrm{C}, 65 \% \mathrm{RH}\right)$

○結晶配向度の測定: 理学電機 $\mathrm{K} . \mathrm{K}$ 整: ガイガーフ レックスを使用し，出力，35 kV，15 mAの CuK

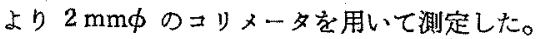

計算は Sack ${ }^{4}$ の方法を利用した（付録 B 参照）

\section{2 実験結果および考察}

3.2 .1 無定形 PET 繊維の延伸試料について

水中 $70^{\circ} \mathrm{C}$ て延伸して得られた試料のヤンク゚率と複屈 折度との関係学 Fig. 3 に白丸で示した。実線は理論式 [(17)武]である。(17) 式からかかるように $E_{0}$ は完全 配向試料のヤング率で女るが，本報では $E_{0}=1700 \mathrm{~kg} /$ $\mathrm{mm}^{2}$ で桜田5) の実測した結晶弹性率の約 1/4 である。 本報の場合は非晶部分のヤング等に近いるのと考允られ る。しかし，ガラス状態での $E_{0}$ は，理想的には結晶弹 性率に近ついてあ上いと思われ，現実には分子鎖末端， fold back 方分子鎖の存在，分子鎖が不均整であり， 直列的に介入する分子閻ひずみが存在することなどのた め，小さくなるので必らう。また $\Delta n_{0}$ の值も重要な因 子であるが，栗山占の $216 \times 10^{-3}$ を用いてす大差ない。 その他，付録 $\mathrm{A}$ の近似にも問題があるが今後の課题とし たい。

交た，Fig.3 の実線は，配向度の低いとき，やや大き な值を示す。これには，要素の force const. の変化な ぞ多くの原因が考觉られるが，ここでは「上述の直列的 К介入する分子間ひずみは，配向度の低いときの法うが 大きいと考文，この点からの理諭式の修正の可能性に ついて考察する。

いま，そのひず学にとすれば，このときのヤング 率 $E^{*}$ は次式で与えられる。

$$
E^{*}=E\left(e_{Z}-e_{s}\right) / e_{Z}
$$


ただし，Eは(17)式である（簃密にはポアンン比の変 化も教虑する必要がある)ここで，理諭的な根拠はない が、次式を仮定する。

$$
e_{s}=K(1-f) e_{z}
$$

たた゚し， $f$ は試料の配向度，Kは定数である。

$K=0.3 ， E_{0}=1900 \mathrm{~kg} / \mathrm{mm}^{2}$ (その他は前と同じ）とし て（18）式を計算すると Fig. 3 の破線となり，実験結 果とかなりよく一致させることができる。

熱処理陚料の結果む同時にプロットしてあるが，熱观 理温度が高く結晶化度が增す徒つて実駼值恃右側へず れ，熱処理による複届折度の增大（結晶化に起因する） はヤング率の值にあまり寄与しない。同一熱処理温度で はデータは一つの曲線上にのり，高配向の試料ではいず れも未熱処理試料の曲線に濑近する。これはヤング率が 非晶部複属折度に強く依存し, 高配向試料では結晶と非 晶の複屈折度が近くなることを示す。

熱処理時に数\%のひずみを与点たるのを Fig. 3 にダ ッシをつけて示したが，大きなヤング率を与える。これ は要素の force const の変化汅るすの之思われる（内

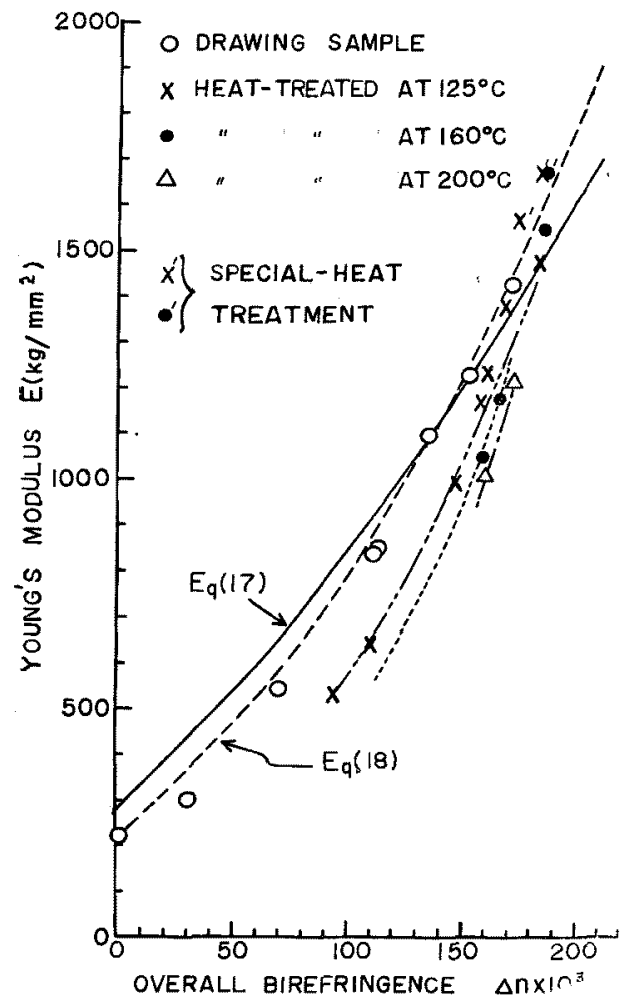

Fig, 3. Relation between Young's modulus and overall birefringence for PET fibres drawn and heat-treated at constant length.
部ひずみによる)。

既報》と同棁化複屈折の加成性を仮定して各試料の非 晶部複屈折度 $\Delta n_{a}$ を求め,これに対してヤング率をプ ロットしな括すと Fig. 4, Fig. 5 の結果を得る。結晶 化度の算出にあたつて非晶部の密度 $\rho_{a}=1.335 \mathrm{~g} / \mathrm{cm}^{3}$ 結 晶の密度 $\rho_{c}=1.445 \mathrm{~g} / \mathrm{cm}^{3}$ を用いたものが Fig. 4 ，末 た非晶部の密度は配向試料ではやや大さなるとい5 Farrow ${ }^{7)}$ その他 ${ }^{8}$ の意見をとり入れ，X線では忹とん ど無定形と判定される 3 倍延伸陚料の密度 $1.355 \mathrm{~g} / \mathrm{cm}^{3}$ を $\rho_{a}$ として用いたものが Fig. 5 である(結晶配向度 は付録 B 参照)。Fig. 4 では各点はかなり左側に移動し ている（E0 を大きくすれば一致の程度を高めることは できるが)。四角，二重丸の印は後述の結晶化後延伸試 料の結果である。

Fig. 5 では Fig. 3 と同じ理論曲線の近くに集密り， かつ一致の程度も良好である。既報1) の結果は (100) 面 のみを用いて配向度を計算したが，自由収縮熱処理につ いてる同様である。

以上の結果はナング率が非晶部の配向度に依存し，結 晶化度结结ま事り依存しないことを示す。これは結晶と

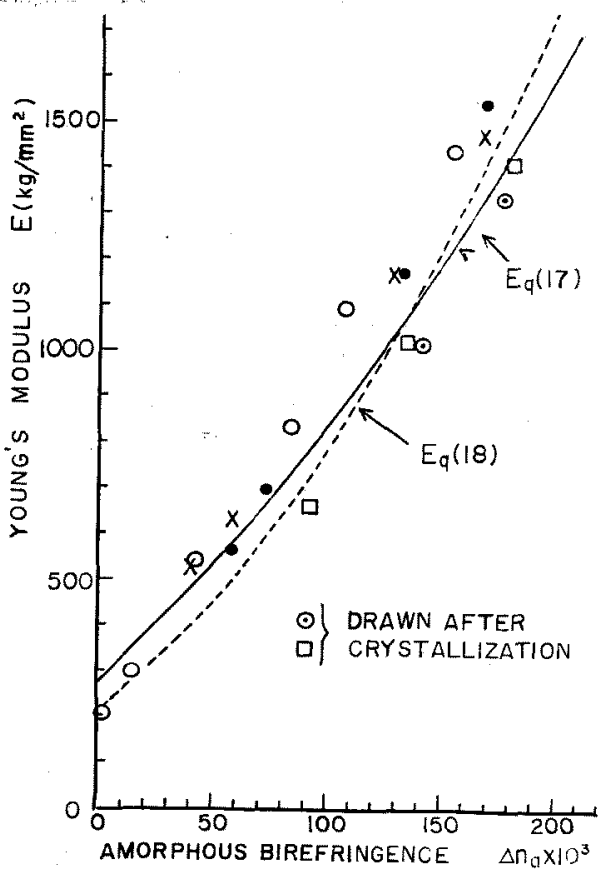

Fig. 3. Relation between Young's modulus and amorphous birefringence (calculated assuming that amorphous density $\rho_{\alpha}$ is 1.335 $\mathrm{g} / \mathrm{cm}^{3}$ ) for drawn and heat-treated PET fibres. 


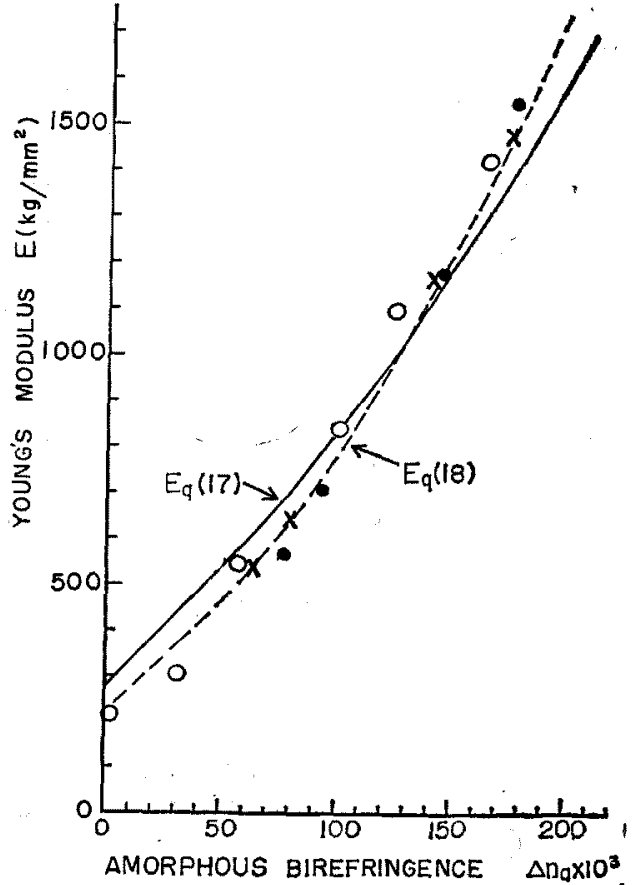

Fig. 5. Relation between Young's modulus and amorphous birefringence (calculated assuming that amorphous density is $1.355 \mathrm{~g}$ / $\mathrm{cm}^{3}$ ) for drawn and heat-treated PET fibers.

非晶とが直列的であることにも関係があるが，むしろが ラス状熊の非晶鎖要素の force const.は結晶鑜のそれ と大差ないことを示惨する。

3.2 .2 結鼠化した後, 延伸した試料

3.1 の方法で結晶化した後, $70^{\circ} \mathrm{C}$ の水中で延伸した 試料についての結果を Fig. 6 に示した。実験値はかな り右側へずれ，延伸試料を再び蓺処理すれば，さらに右 側へずれる。前と同橡に $\Delta n_{a}$ を求めて Fig. 4 にプ口 ットしたが，無定形物の延伸試料比し（同一 $\Delta n_{a}$ K 対しヤング率は小さい。な枋 Fig. 6 で黒丸に棒の入 つた印は $160^{\circ} \mathrm{C}$ のリコン油中に 30 分漫せき後，その ま延伸した試料の結果で高配向度の試料が得られこの 試料では整定形物の延伸試料学䇣張熱処理したものと大 体同様な結果を与光る。結晶化試料の水中 $70^{\circ} \mathrm{C}$ 程度の 延伸で依 fold 構造がかなり残り ${ }^{92}$ fold back する分子 鎖も多く，加分子鑟の切断も生じているのてはないか と思われる。理論式の上で被的小さく $E_{0}, G_{0}$ が小さ いと考党ればよいでめろう。

\section{4. ま と め}

ガラス温度以下に和ける PET 蟣維の微小変形につい

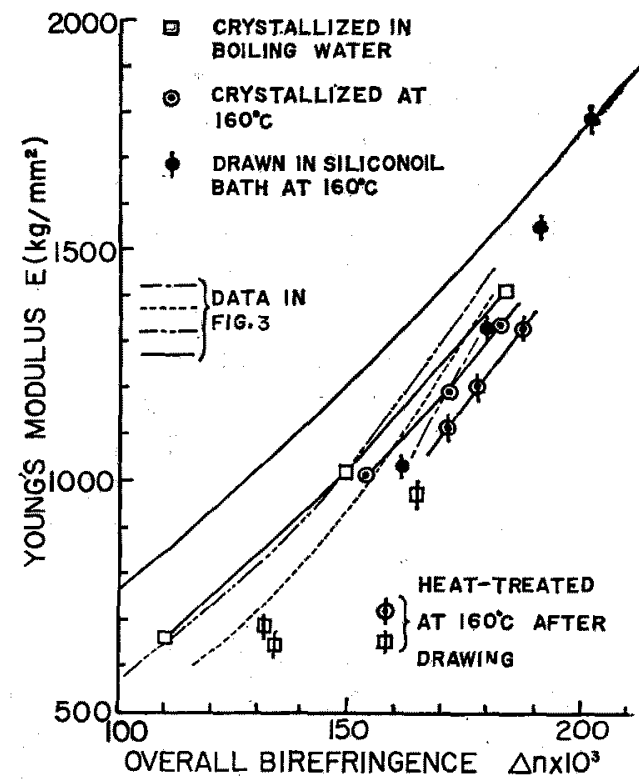

Fig. 6. Relation between Young's modulus and overall birefringence for PET fibres drawn in water at $70^{\circ} \mathrm{C}$ after crystallization.

て既報の理諭を修正し，かつ新しい見地から考察を加 え, 次の結果を得た。

1. 既報の $E_{g}$ は要素の回転にもとつく要素間相互変 位に対応するすのと考学られ，要素の回転角惊(12)式， 試料のヤング率は(17)式で与えられる。また，直列的に 介入する分子間ひずみを考えることにより(17)式を修正 すれば，雪験結果とかなりよく一致させることができ る。

2. 定長熱処理試料についても，既眽の自由取縮熱処 理試料と同㥞に，ヤング率は非晶部複屈折度 $\Delta n_{a}$ に上 り依存し，いわゆる結晶化度の影響は少ない。な扰，結 晶化度の算出にあたつて，無定形部分の密度が延伸試料 では大きくなると考えた浑 5 が，理論式との一致は良好 である。

3. 結晶化した後, 水中 $70^{\circ} \mathrm{C}$ て延伸した試料では, 同一の $\Delta n_{a}$ に対してヤング率は小さくなるが， $E_{0}, G_{0}$. の佪を小さくとれば理論式が成立する。しかし， $160^{\circ} \mathrm{C}$ 延伸試料で流(高倍率では)，無定形物の延伸試料希 160 -

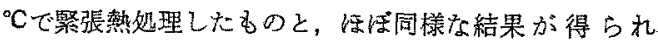
る。

4. 以上の実験結果は次のことを示唆する。a）ガ ス状感の非晶鎖要素の force const. 恄晶鎖の圭九と 大差なく，分子鎖末端， fold back 与る分子鎮の依存， 直列的に介入する分子間ひする゙の存在などが $E_{0}$ 低下 
させる。b）結晶化後，温延伸試料では fold 構造がか なり存在するのではないか。

\section{5. おわりに}

fold 構造の存在 結晶部の寄与など，さらに裹付けと なる実験を行なう必要があるが，既報より合理的な理論 式を導くことができた。

有益なご助言をいただいた東工大石川欣造教授，また X線回折にご協力いただいた当所栗田技官に感謝いたし ます。

付 録 A

$\left\langle\cos ^{4} \theta\right\rangle,\left\langle\cos ^{2} \theta \cdot \sin ^{2} \theta\right\rangle$ の求的方

本文の (3),(4) 式からかかる上5に

$$
\left\langle\cos ^{4} \theta\right\rangle=\int_{0}^{\pi / 2} 2 P(\theta) \sin \theta \cdot \cos ^{4} \theta \cdot d \theta
$$

である。

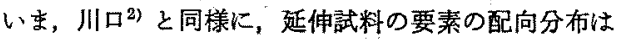
無配向試料の分子鎖末端ベクトルが affin 変形したと きの，七グメントの分布と同しであると仮定すれば， $P(\theta)$ は次式で与えられる（延伸比の小さなとき）。

$2 P(\theta) \cong 1+\left\{B_{0}{ }^{2}\left(\lambda^{3}-1\right) / 18 \lambda\right\}\left(3 \cos ^{2} \theta-1\right)(A-2)$

ただし， $B_{0}=3 R_{0} / J a_{0} ; R_{0}$ ：無配向試料の分子鎖末端 間ペクトルの長さ， $a_{0}, J:$ 無配向試料の分子鍞ベクトル を構成するセグメントの長さ，怙よび数； $\lambda$ : 延伸比

このときの〈 $\left.\cos ^{4} \theta\right\rangle$ は次のよ5になる。

$$
\begin{array}{ll} 
& \left\langle\cos ^{4} \theta\right\rangle=1 / 5+4 f / 7 \\
\text { ただし } & f=\left(3\left\langle\cos ^{2} \theta\right\rangle-1\right) / 2
\end{array}
$$

しかし，延伸比の大きなときは（A-2）式は成立せず， 要素の分布は分子鎖べトルの分布に近いものと考光た 涪らがよい。このときの $P(\theta)^{17)},\left\langle\cos ^{4} \theta\right\rangle$ は

$$
\begin{gathered}
2 P(\theta)=\lambda^{3} /\left\{1+\left(\lambda^{3}-1\right) \sin ^{2} \theta\right\}^{3 / 2} \\
\left\langle\cos ^{4} \theta\right\rangle=\frac{\lambda^{2}}{2\left(\lambda^{3}-1\right)^{2}} \\
\left\{2 \lambda^{3}+1-\frac{3 \lambda^{3}}{\left(\lambda^{3}-1\right)^{1 / 2}} \tan ^{-1}\left(\lambda^{3}-1\right)^{1 / 2}\right\}
\end{gathered}
$$

となる。試料の複屈折度から〈 $\left.\cos ^{2} \theta\right\rangle$ を求め,から

$$
\left\langle\cos ^{2} \theta\right\rangle=\frac{\lambda^{3}}{\lambda^{3}-1}\left\{1-\frac{1}{\left(\lambda^{3}-1\right)^{1 / 2}} \tan ^{-1}\left(\lambda^{3}-1\right)^{1 / 2}\right\}
$$

から計算した入を用いて〈 $\left.\cos ^{4} \theta\right\rangle$ を求めることができる。 な和（A-5) 式は， $\lambda\left\langle 3\right.$ のと $\left\langle\cos ^{2} \theta\right\rangle-0.12$ て近似 され，試料の複屈折度から逆算した $\lambda$ なたは $\left\langle\cos ^{2} \theta\right\rangle を$ 用いる場合には，(A-3) 式の計算値と大差ない（同じ延 伸比では非常に異なる)。従つて, 本報では（A-5）式に より計算した。また $\left\langle\cos ^{2} \theta \cdot \sin ^{2} \theta\right\rangle$ は $\left\langle\cos ^{2} \theta\right\rangle-\left\langle\cos ^{4} \theta\right\rangle$ として求められる。

弾密には Legendre 多項式を用いた計算が必要であ
るが15)，今後の課䁲としたい。

付 録 B

$\mathrm{X}$ 線によるPET 緎維の結晶配向度の測定について

X線による結晶配向度の测定法としては，適当な媔面

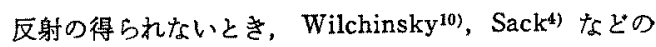
方法により〈 $\left.\cos ^{2} \theta\right\rangle$ を求めて計算するのが正しいと思わ れる(とくに複屈折に上る評価と関連つけようとする場 合）。しかし実際にこれを正しく行ならには実験的な困 難が伴ない，実用的には半価幅法でよいとする上田ら の報告もむる。ここでは基本的には前者の方法を利用し ている G. Farrow ${ }^{12)}$ 栗山ら ${ }^{6)}$ の方法を参考にして配向 度を求める際の問題点について $2 ， 3$ 考察し，また半価 幅法との比較検討を行なつてみだ。

\section{B·1 結晶面に上る X 線干渉强度}

PET 結晶 (100) 面による干涉摆の強度分布を模式図 で示すと Fig. 7(a)，(b)のよ5以なる。(a)は配向度 の高いもの，(b)は低いものであるが，(a)からわかる 上5に (111)，(112) の干齿の裾が重くなつてくる。 (010) 面についてる同様で(011)の千涉の裾が重なる。 （a）図で性，その分離は比較的容易であるが，（b 図で は非常に困難で実際より低い配向度を与允ることにな る。

次に上田 ${ }^{11)}$ 子指摘しているよ5に，非結晶性干歩曲線 の求め方にも問題がある。G.Farrow ${ }^{12)}$ は配向試料の 非結晶干啮強度は方位角に上り変化するものとし，次の 上5にして求めている。まず，ある方位角での $2 \theta$ 方向
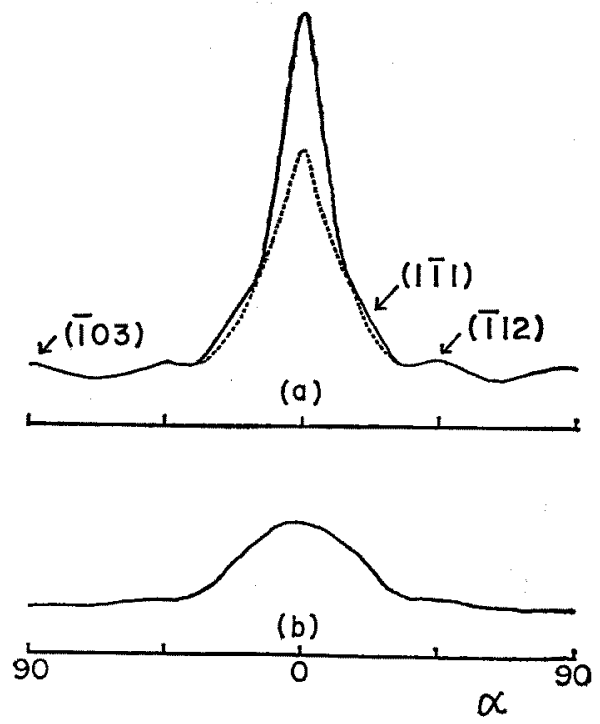

Fig. 7. Illustrations of the distribution of $\mathrm{X}$ ray diffraction intensity on the Debye ring for (100) plene of drawn PET fibres. 


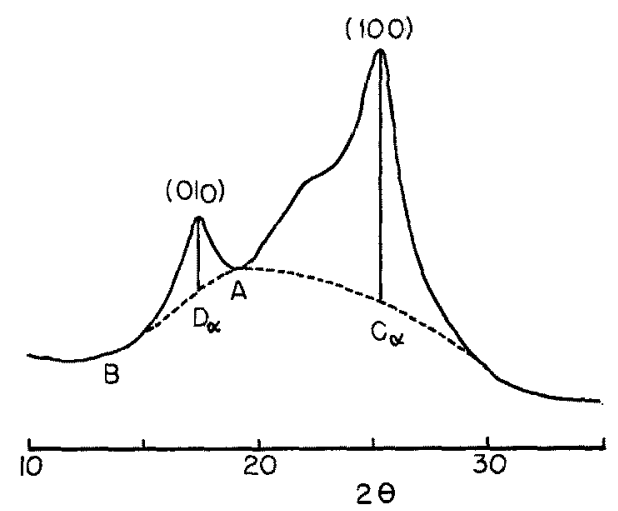

Fig. 8. Illustration of radial intensity distribution and background scatter for the drawn PET fibres.

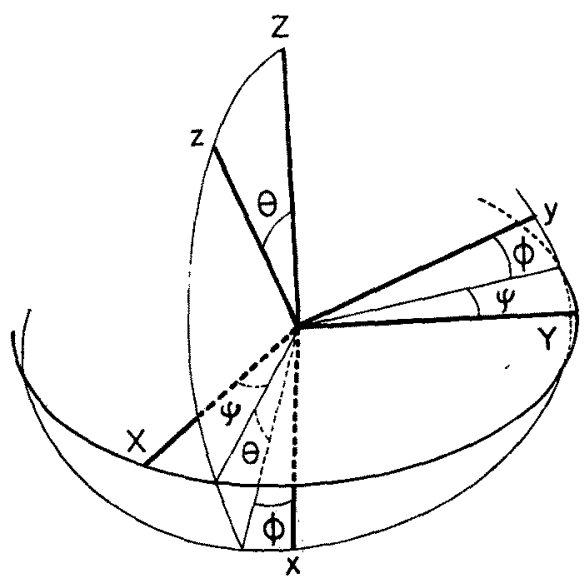

Fig. 9. Illustration of Eular angle : $Z$ is fibre axis ; $z$ is the $c$ axis of a crystallite.

の干漇強度曲線を求め（Fig. 8) A 淿よびBでは結晶に よる下涉強度需であるとして点線のような非結晶干沙

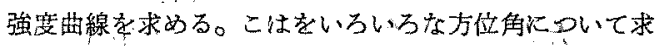

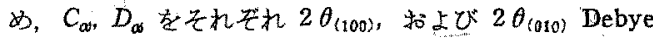
環上の方位角 $\alpha$ に括ける非結晶干涉強度としている。結 果は Fig. 7 の点線の上弓である。しかし，この方法に ならつて高速回転試料の $2 \theta$ 万向干涉強度曲線から非結 晶干啮を分離し，結晶化度を求めると非常に小さな值と

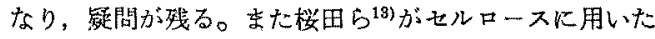
$2 \theta$ の Debye 環上の最低值を非結晶干涉強度とする力

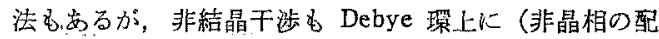

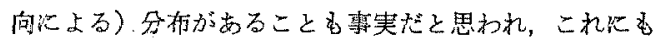
闍題はむる。

$\mathbf{B} \cdot 2$ 結晶 $c$ 軸配向度 (Sack ${ }^{4}$ の方法による)

PET 結晶の $c$ 軸配向度は, 普通 $(h, k, 0)$ 面の干渉
強度から求められるが，三科晶系のため厄介である。い ま織維軸を $Z$ 軸とする遖交座標系 $(X, Y, Z)$ において, 結晶 $c$ 軸を $z$ 軸とする結晶に固定した直交厘栖采 $(x, y$, z) のオイラー角を $(\theta, \phi ， \psi)$ とする。Sack的によれば， 結晶の分布を $\omega(\theta, \phi ， \psi)$ で表わすと（Fig. 9) $\omega(\theta, \phi, \phi)$ かi $\varphi$ 飞無関伱

$$
\begin{aligned}
& \omega(\theta, \phi)=\omega(\theta,-\phi) \\
& \omega(\theta, \phi)=\omega(\pi-\theta, \phi)
\end{aligned}
$$

が成立するとき，次式が得られる。

$$
\begin{array}{r}
f_{c}=2\left(f_{010} \cos 2 \varphi_{100}-f_{100} \cos 2 \varphi_{010}\right) / \\
\left(\cos 2 \varphi_{010}-\cos 2 \varphi_{100}\right)
\end{array}
$$

ただし， $f_{c}$ : 瀻維軸に対する結晶 $c$ 軸の配向度， $f_{100}$, $f_{010}$ : (100), (010) 备面の法線の瀻維軸に対する配向 度; $\varphi_{100} ， \varphi_{010}$ ：各面の法線と $x$ 軸とのなす角とする。

(100) 面, あるいは (100) 面の法線が $Z-z$ 平面に対 称的に分布しているときは，この法線家 $x$ 軸にとればよ く, $\varphi_{100}=0, \varphi_{010}=59.4^{\circ}$ (法線のなす角で $a, b$ 軸のな す角ではない:Bunn ${ }^{14)}$ の単位胞加ら計算した。

(010) 面が $Z-z$ 平面儿対称的に分布しているときは， $\varphi_{100}=59.4^{\circ}, \varphi_{010}=0$ となる。

結晶配向が $z$ 軸のまわりにランダムであれば， $f_{100}=$ $f_{010}$

$$
f_{c}=-2 f_{100}=-2 f_{010}
$$

となる（以上いすれれ $c$ 軸は擮維軸のまわりにランダム であると仮定している)。

X線により $f_{100}, f_{010}$ を求めてば， $x$ 軸党適当にとり $f_{\varepsilon}$ を求めることができる。

\section{B.3 半価巾法による $\mathrm{c}$ 軸配向度}

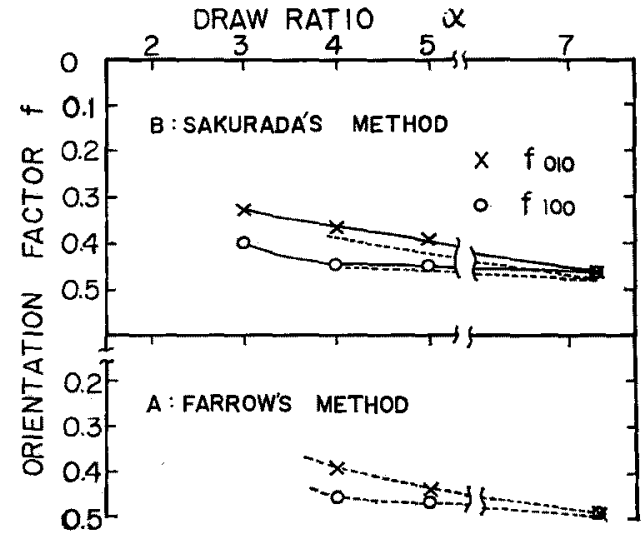

Fig. 10. The change of orientation factor with draw ratio for the normal of (100) and (010) plane of drawn PET fibres, and comparison of two methods in which background scatter is seperated. 

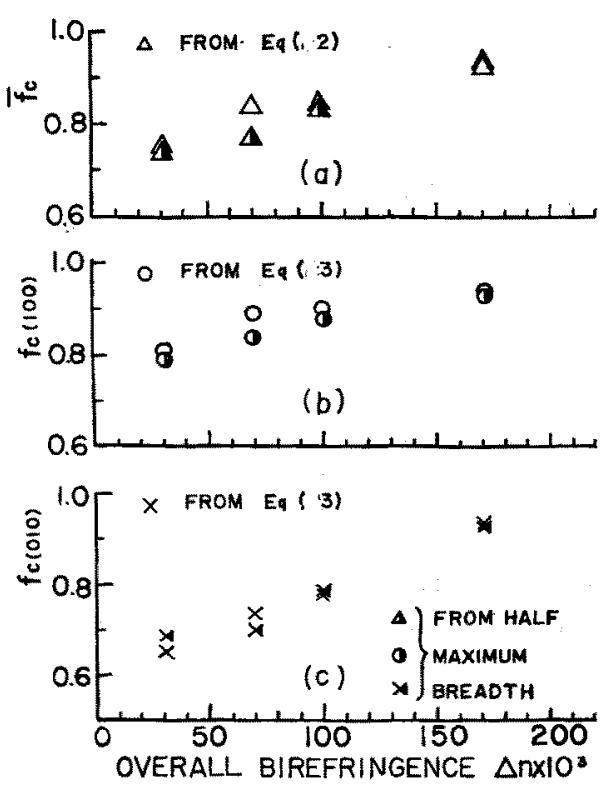

Fig. 11. Comparison of the $c$ axis orientation calculated from eq. (B-2) and (B-3) by Sack with one from half maximum breadth.

$(\mathrm{h}, \mathrm{k}, 0)$ 面の $2 \theta$ Debye 環上の強度解の半洒 幅を $H^{0}$ とすれば（赤道上にピークがあるとき）

$$
f_{c}=(180-H) / 180
$$

によつて求められる。この場合休物理的意昧がわからな いので $(100)$ ，(010) 各面の平垉颠を求める。

\section{B.4実鈳結果および考案}

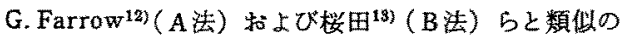

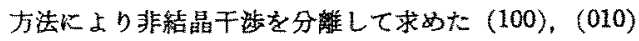
各面の法線の配向度を延伸培率に対してプロットすると Fig. 10 の結果を得る。(010) 面の法線の配向度加小さ く（免の力向に対し）でているが，これはとくに配向度 の低いとき $(0 \overline{1} 1)$ 面の干渉がうまく分離できないとに

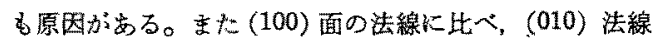
の注5か゚ A, B 雨法の差が大きいが，これも同样であ

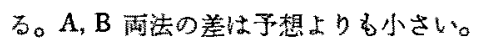

半価幅法之の比较：上記 B 法の結果方ら, (010)面法線 を $x$ 軹として，(B-2) 式から求めた $(c)$ 軹配向度如上び 別に半価䒇法飞より $(100) ，(010)$ 各面について(B-4)或 から求的た $c$ 軸配向度の平均值を，杂れ艺れ試料の複屈 折度に対してプロットすると Fig，11，(a)のよ5Kな

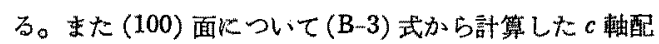

向度扰よび半価幅法から求めた $c$ 軸配向度を(b) に， (010) 面についての結果を(c)に示した。

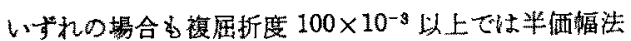
で十分であると思われる。(100) 面法線を

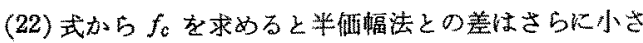
くなるが，x軸のとり方はいずれがよいか簡単比確かか

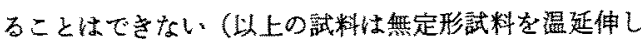
たの)。

\section{B.5 まとめ}

1. 非結晶干啮强度の求方方として G. Farrow 岕よ び桜田らと類似の方法を检討した結果：a）無定形試料

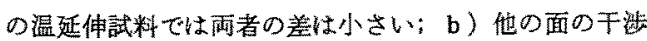
の分離のほうが重要である。

2. 非結晶干啮度桜田の方法で分離し， Sackの 万法と半価幅淁とにより $f_{c}$ を求好結果：a）配向度 の高い試料で半価幅法て十分である。b) Sackの方 法は合理的ぜあるが、 $x$ 軸のとり方問題がする。

付記 本報では接田の方法で非結昆干競分離し，物 理的意味塞視して Sack の方法により求めた $f_{c}$ を使

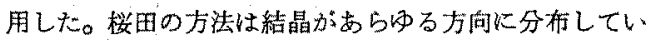
るときは使用できない。な格，この報告の一部㤌昭和 39 年奉，40 年秋の蟣維学会研究発表会で講演した。

\section{文萳}

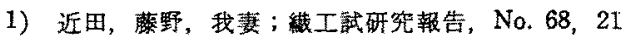
(1964)

2) 川1口; 高化, 14, 176 (1957)

3) 近田”滕野，我妻；䋐学誌，21，246(1965)

4) R. A. Sack; J.Polymer Sci, 54, 543 (1961)

5) 椶田, 伊藤；高化，19，300(1962)

6) 慗山，富板，白整；裁学薏，20，431 (1964)

7) G. Farrow, I. M. Ward ; Polymer, 1, 300(1960)

8) W. O.Statton; J. Appl. Polymer Sci., 7, pp. 803 (1963)

9）たと文ば河合；泼学落，22，S138(1966)

10) Z.W.Wilchinsky ; J. Appl, Physics, 30, 792 792 (1959)

11)上田, 温品; 高化, 21，337 (1964)

12) G. Farrow, Miss J. Bagley; Text. Res. J., 32, 587 (1962)

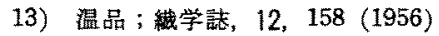

14) J. H. Wakelin, et al.; J. Appl. Polymer Sci., 26. 286 (1955)

15) 河合，野村；高分子，15，889 (1966)

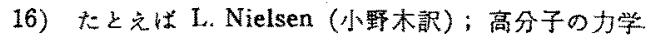
的性臂，p.8(化学同人)

17) W. Kuhn, F. Grün ; Kolloid-Z., 101, 248 (1942) 